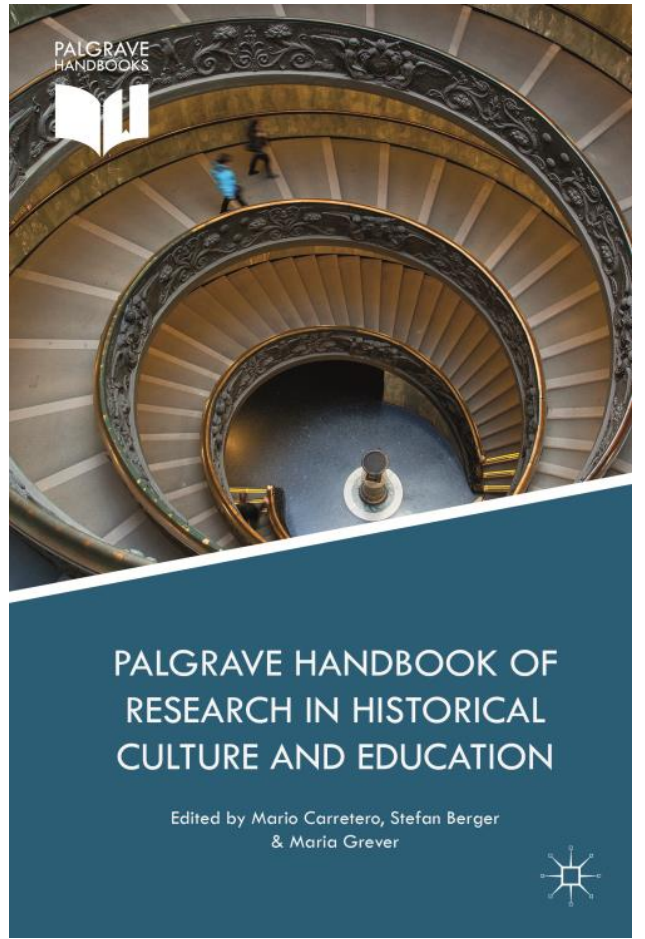

Hardback 9781137529077

$2016 £ 150.00 \$ 235.00$

eBook 9781137529084

$2016 £ 120.00 \$ 179.00$

\section{Palgrave Handbook of Research in Historical Culture and Education}

\author{
Edited by Mario Carretero, Stefan Berger, and Maria Grever \\ Coming Soon
}

\begin{abstract}
Mario Carretero is Professor at Autonoma University of Madrid, Spain, where he was Dean of the Faculty of Psychology, and Researcher at FLACSO, Argentina.

Stefan Berger is Professor of Social History and Director of the Institute for Social Movements at Ruhr University Bochum as well as Executive Chair of the Foundation History of the Ruhr.

Maria Grever is Professor of History and Theory and Director of the Center for Historical Culture at Erasmus University Rotterdam, the Netherlands.
\end{abstract}

"The editors are to be congratulated on providing scholars and students with an invaluable compendium of original and up-to-date materials on the theory and practice of history teaching from a huge range of diverse cultures. At a time of increasing pressure to nationalize history teaching, it is especially useful to have this uniquely international and interdisciplinary set of provocative analyses essential for much-needed comparative global perspectives".

- David Lowenthal, University College, London, UK.

"A rich and diverse collection of essays reflecting the state of the art in the unexplored field at crossroads between multiple disciplines, in particular cultural history, memory and heritage studies, and education understood in a wide sense, not at all limited to schools. A multinational approach offering innovative insights into history teaching and learning, and opening up the search for present and future developments of educational and general interest".

- Luisa Passerini, European University Institute, Florence, Italy.

"An indispensable volume for anyone who wants to understand the state of history teaching today."

- Samuel Wineburg, Stanford University, USA.

About the book

The handbook provides a broad overview of current research and theories on historical culture and education. It consists of thirty-nine chapters divided into four parts: I. Historical Culture: Conceptualizing the Public Uses of History; II. The Appeal of the Nation in History Education of Postcolonial Societies; III. Reflections on History Learning and Teaching; IV. Educational Resources: Curricula, Textbooks and New Media. The handbook integrates contributions of researchers from history, historical theory, education, collective memory, museum studies, heritage, social and cognitive psychology, and other social sciences, stimulating an interdisciplinary dialogue. Contributors come from various countries of Northern and Southern America, Europe, North-Africa, Australia and Asia, providing an international perspective that does justice to the complexity of this field of study. The Palgrave Handbook of Research in Historical Culture and Education provides state-of-the-art research, focusing on how citizens and societies make sense of the past through different ways of representing it. 


\section{Table of Contents}

Acknowledgements

List of Contributors

1. Introduction: Historical Cultures and Education in Transition; Mario Carretero, Stefan Berger, Maria Grever

\section{PART I. Historical Culture: Conceptualizing the Public Uses of History}

2. History Writing and Constructions of National Space - The Long Dominance of the National in Modern European Historiographies; Stefan Berger

3. Historical Consciousness and Historical Thinking; Peter Seixas

4. Historical Culture: a Concept Revisited; Maria Grever and Robbert-Jan Adriaansen

5. Historical Rights to Land: How Latin American States Made the Past Normative and What Happened to History and Historical Education as a Result; Tamar Herzog

6. 'The Times They Are a-Changin'. On Time, Space and Periodization in History; Chris Lorenz

7. Democracy and History Museums. Museo de America; Marisa González de Oleaga

8. Illustrating National History; Peter Burke

9. Film, the Past, and a Didactic Dead End: From Teaching History to Teaching Memory; Wulf Kansteiner

10. Historical Edutainment: New Forms and Practices of Popular History?; Barbara Korte and Sylvia Palatschek

11. The Jurassic Park of Historical Culture; Antonis Liakos and Mitsos Bilalis

\section{PART II. The Appeal of the Nation in History Education of Postcolonial Societies}

12. Teaching National History to Young People Today; Jocelyn Letourneau

13. Echoing National Narratives in English History Textbooks; Tina van der Vlies

14. Colonial and Postcolonial Contexts of History Textbooks; Susan Grindel

15. History in French Secondary School: a Tale of Progress and Universalism or a Narrative of Present Society?; Nicole TutiauxGuillon

16. National Narratives and the Invention of Ethnic Identities in Morocco; Norah Karrouche

17. Constructing Identity and Power in History Education in Ukraine: Approaches to Formation of Peace Culture; Karina $V$. Korostelina

18. Postcolonial Discourses and Teaching National History. The History Educators' Attempts to Overcome Colonialism in the Republic of Korea; Sunjoo Kang

19. History for Nation-Building: the Case of Greece and Turkey; Herculas Millas

20. Conflicting Narratives about Argentinean "Conquest of the Desert". Social Representations, Cognitive Polyphasia, and Nothingness; Alicia Barreiro, José Antonio Castorina, Floor van Alphen

21. After Empire: the Politics of History Education in a Postcolonial World; Andrew Mycock

\section{PART III. Reflections on History Learning and Teaching}

22. What to Teach in History Education When the Social Pact Shakes?; Alberto Rosa and Ignacio Bresco

23. The Power of Story: Historical Narratives and the Construction of Civic Identity; Helen Haste and Ángela Bermúdez

24. Shared Principles in History and Social Science Education; Keith Barton

25. Concepts Acquisition and Conceptual Change in History; Maria Rodriguez-Moneo and Cesar Lopez

26. Social Representations Concepts of the Past and Competences in History Education; Dario Páez, Magdalena Bobowik and James Liu

27. Teaching History Master Narratives: Fostering ImagiNATIONS; Mario Carretero

28. Organizing the Past: Historical Accounts, Significance and Unknown Ontologies; Lis Cercadillo, Arthur Chapman and Peter Lee 29. Historical Reading and Writing in Secondary School Classrooms; Jeffrey Nokes

30. Engaging Students in Historical Reasoning: the Need for Dialogic History Education; Carla van Boxtel and Jannet van Drie

\section{PART IV. Educational Resources: Curricula, Textbooks and New Media}

31. Bridging the Gap - Comparing History Curricula in History Teacher Education in Western Countries; Nicola Brauch 32. Cultural Wars and History Textbooks in Democratic Societies; Tony Taylor and Stuart Macintyre

33. Trends and Issues Surrounding the Reading of Historical Texts in the Republic of Korea; Hohwan Yang

34. History Education Reform in Twenty-First Century China; Side Wang, Yueqin Li, Zhongjie Meng and Chencheng Shen

35. Tools in Teaching Recent Past Conflicts. Constructing Textbooks beyond National Borders; Robert Maier

36. Emotional, Moral and Symbolic Imagery of Modern Russian History Textbooks; Tatyana Tsyrlina and Michael Lovorn

37. Educational Websites on the Memory of Slavery in Europe: the Ongoing Challenge of History Teaching; Stephan Klein

38. Social Media, New Technologies and History Education; Terry Haydn and Kees Ribbens

39. The Neverending Story about Heritage and Museums: Four Discursive Models; Mikel Asensio and Elena Pol Index

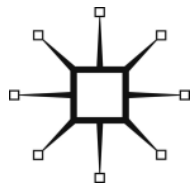

